\title{
Lead toxicity thresholds in 17 Chinese soils based on substrate-induced nitrification assay
}

\author{
$\mathrm{Ji} \mathrm{Li}^{1,2}$, Yizong Huang, ${ }^{1, *}$, Ying $\mathrm{Hu}^{2}$, Shulan $\mathrm{Jin}^{3}$, Qiongli Bao ${ }^{1}$, Fei Wang ${ }^{2}$, \\ Meng Xiang ${ }^{2}$, Huiting Xie ${ }^{2}$ \\ 1. Agro-Environmental Protection Institute, Ministry of Agriculture, Tianjin 300191, China \\ 2. Research Center for Eco-Environmental Sciences, Chinese Academy of Sciences, Beijing 100085, China \\ 3. Shangrao Normal University, Shangrao 334000, China
}

\section{A R T I C L E I N F O}

Article history:

Received 5 June 2015

Revised 25 August 2015

Accepted 1 September 2015

Available online 29 January 2016

Keywords:

$\mathrm{Pb}$ toxicity

Leaching

Nitrification assay

Risk assessment

\begin{abstract}
A B S T R A C T
The influence of soil properties on toxicity threshold values for $\mathrm{Pb}$ toward soil microbial processes is poorly recognized. The impact of leaching on the $\mathrm{Pb}$ threshold has not been assessed systematically. Lead toxicity was screened in 17 Chinese soils using a substrate-induced nitrification (SIN) assay under both leached and unleached conditions. The effective concentration of added $\mathrm{Pb}$ causing 50\% inhibition (EC50) ranged from 185 to $>2515 \mathrm{mg} / \mathrm{kg}$ soil for leached soil and 130 to $>2490 \mathrm{mg} / \mathrm{kg}$ soil for unleached soil. These results represented $>13$ - and $>19$-fold variations among leached and unleached soils, respectively. Leaching significantly reduced $\mathrm{Pb}$ toxicity for $70 \%$ of both alkaline and acidic soils tested, with an average leaching factor of 3.0. Soil pH and CEC were the two most useful predictors of $\mathrm{Pb}$ toxicity in soils, explaining over $90 \%$ of variance in the unleached EC50 value. The relationships established in the present study predicted $\mathrm{Pb}$ toxicity within a factor of two of measured values. These relationships between $\mathrm{Pb}$ toxicity and soil properties could be used to establish site-specific guidance on $\mathrm{Pb}$ toxicity thresholds. (c) 2016 The Research Center for Eco-Environmental Sciences, Chinese Academy of Sciences.
\end{abstract}

Published by Elsevier B.V.

\section{Introduction}

Lead $(\mathrm{Pb})$, a nonessential element, is frequently implicated in soil pollution. The potential environmental risk of $\mathrm{Pb}$ has received increasing attention because of the presence of $\mathrm{Pb}$ worldwide and the potential exposure of terrestrial organisms, wildlife and human beings (Watanabe, 1997). China is now the world's largest producer of lead ore and refined lead, and also the largest refined lead consumer in the world. The problem of soil lead pollution arose and became serious with the rapid development of the mining and smelting industry. For the past few years, efforts have been made to investigate $\mathrm{Pb}$ toxicity thresholds in European and Australian soils with various toxicity assays, such as plant growth (Cheyns et al., 2012) and microbial assays (Rusk et al., 2004). However, few such studies have been reported for $\mathrm{Pb}$ toxicity in Chinese soils.

It is well recognized that soil physicochemical properties are important factors in predicting the toxicity and bioavailability of metals, such as copper (Cu), zinc ( $\mathrm{Zn})$, nickel (Ni) and lead $(\mathrm{Pb})$, in soils (He et al., 2015; Broos et al., 2007; Oorts et al., 2006b; Rooney et al., 2006). Bradham et al. (2006) concluded that soil pH was the most important factor related to $\mathrm{Pb}$ bioavailability and toxicity to earthworms. Although it is widely recognized that soil properties play a crucial role in affecting toxicity (Cremazy et al., 2013; Li et al., 2011; Li et al., 2009, 2010; Oorts et al., 2006b, 2007; Rooney et al., 2006, 2007), few countries have incorporated

\footnotetext{
* Corresponding author. E-mail: hyz@rcees.ac.cn (Yizong Huang).
} 
soil physicochemical properties in their soil quality guidelines. With scientific data like that provided by the present studies, the ecologically relevant Chinese soil guidelines could improve more quickly.

Laboratory toxicological assays based on fresh spiking of metals into soils are not able to predict the chronic toxicity of metals in the field (Schwertfeger, 2011; Oorts et al., 2006a; Giller et al., 1998). Spiking soils with soluble metal salts not only increases the metal content of a soil but also increases the ionic strength of the soil solution and decreases the soil $\mathrm{pH}$ by replacement of protons from the exchange complex with metal cations. These changes in soil properties are artifacts of spiking with soluble metal salts and affect the metal bioavailability and soil microbial response (Speir et al., 1999). Aging processes and loss of excess salts by leaching may contribute much to this discrepancy (Oorts et al., 2006a). Therefore, leaching after metal addition has been proposed as an agreed approach to reduce the chemical artifacts of the spiking procedure (e.g., salt effect, increased metal solubility) that can decrease the ecological relevance of soil toxicity assays (Schwertfeger, 2011; Smolders et al., 2009; Oorts et al., 2006a, 2007; Bongers et al., 2004; Stevens et al., 2003). The effects of leaching on $\mathrm{Pb} \mathrm{ECx}$ values in soils require further study on a larger scale before leaching is used as a standard protocol in soil toxicity assays.

Soil microbial processes were selected because of their high sensitivity to metal addition, and these processes are considered to predict soil function in terrestrial risk assessments. Based on this rationale, substrate-induced nitrification (SIN) was selected as the end point to assess the potential risks of $\mathrm{Pb}$ in soil. The aims of this study were: (1) to determine the effect of leaching on $\mathrm{Pb}$ toxicity as it affects the SIN assay in a range of Chinese soils, and (2) to develop quantitative relationships between soil physicochemical properties and the toxicity thresholds.

\section{Materials and methods}

\subsection{Soils}

Seventeen uncontaminated topsoils were collected throughout China (see Fig. 1 and Table 1 for detailed information). The soils represent the major soil types and cover a wide range of soil $\mathrm{pH}$ and organic matter content of arable soils, which are expected to affect the toxicity and bioavailability of $\mathrm{Pb}$ in soils. Five surface soil samples $(0-10 \mathrm{~cm})$ were collected at each site. Soil samples were sealed in polyethylene bags and stored at 4 prior to analysis.

The soils were air-dried and sieved through $2 \mathrm{~mm}$ mesh, and soil physicochemical properties were determined. Soil $\mathrm{pH}$ was measured in $0.01 \mathrm{~mol} / \mathrm{L} \mathrm{CaCl} 2$ (soil:water ratio, 1:5) after shaking for $1 \mathrm{hr}$ and allowing to settle for $30 \mathrm{~min}$. Cation exchange capacity (CEC) was measured with $1 \mathrm{~mol} / \mathrm{L}$ ammonium chloride at pH 7. Organic carbon was calculated as the difference between total and inorganic carbon content. Total carbon and nitrogen were determined by ignition with a Variomax CNS elemental analyzer (Vario EL III, Germany). The clay content of soils was determined through particle size analysis after destruction of organic matter with $\mathrm{H}_{2} \mathrm{O}_{2}$, removal of carbonate and soluble salts

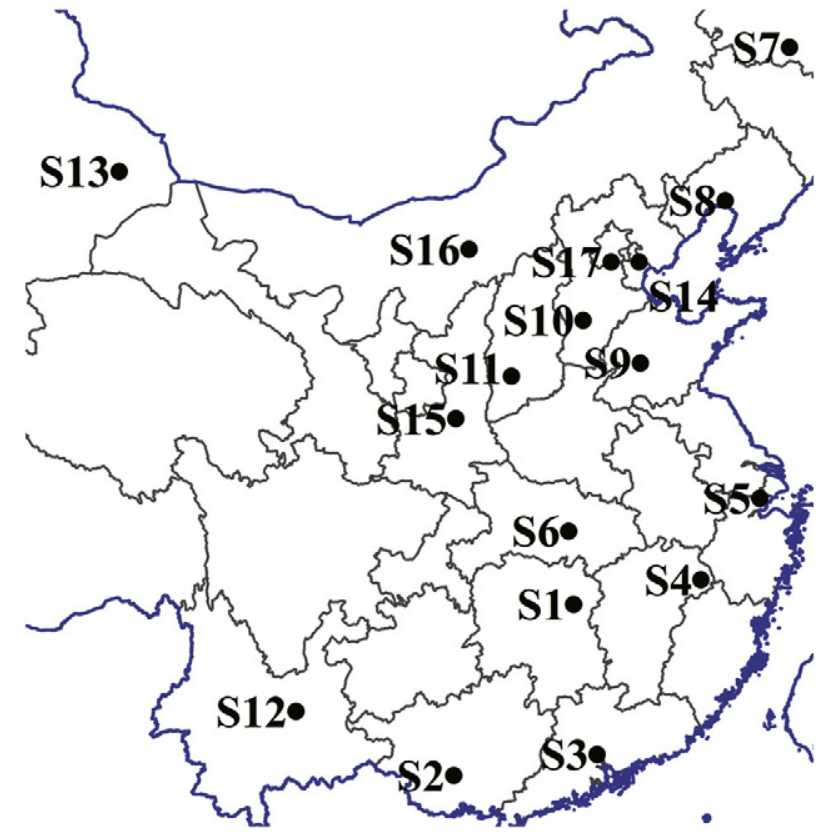

Fig. 1 - Location of soil sampling sites.

with $\mathrm{HCl}$, and dispersion with sodium hexametaphosphate (Gee and Bauder, 1986).

Total $\mathrm{Pb}$ concentrations were determined by inductively coupled plasma-optical emission spectrometry (ICP-OES; Optima 8300 DV, PerkinElmer, USA) or inductively coupled plasma-mass spectrometry (ICP-MS; Agilent, USA) after boiling aqua regia $\left(\mathrm{HNO}_{3}: \mathrm{HCl}=1: 3\right)$ extraction. All soil properties are expressed on an oven-dried (105) weight basis (Table 1).

\subsection{Soil treatments}

Sieved, air-dried soil was spiked with $\mathrm{Pb}$ (as $\mathrm{Pb}(\mathrm{NO})_{3}$ in deionized water, $50 \mathrm{ml} / \mathrm{kg}$ ) at 25, 50, 100, 200, 400, 800 and $1000 \mathrm{mg} \mathrm{Pb} / \mathrm{kg}$ dry soil for soils with $\mathrm{pH}<5 ; 50,100,200,400$, 800,1200 and $1600 \mathrm{mg} \mathrm{Pb} / \mathrm{kg}$ dry soil for soils with $\mathrm{pH}$ from 5 to 7; and 100, 200, 400, 800, 1200, 1600 and $2400 \mathrm{mg} \mathrm{Pb/kg}$ dry soil for soils with $\mathrm{pH}>7$. The spiked soils were incubated for 1 day at $100 \%$ maximum water holding capacity (MWHC), then air-dried at $25^{\circ} \mathrm{C}$, and sieved through 2-mm mesh.

The freshly spiked soils were leached with artificial rainwater $\left(\mathrm{CaCl}_{2} 5 \times 10^{-4} \mathrm{~mol} / \mathrm{L}, \mathrm{Ca}\left(\mathrm{NO}_{3}\right)_{2} 5 \times 10^{-4} \mathrm{~mol} / \mathrm{L}\right.$, $\mathrm{MgCl}_{2} 5 \times 10^{-4} \mathrm{~mol} / \mathrm{L}, \mathrm{Na}_{2} \mathrm{SO}_{4} 10^{-4} \mathrm{~mol} / \mathrm{L}$, and $\mathrm{KCl} 10^{-4} \mathrm{~mol} / \mathrm{L}$, $\mathrm{pH}$ 5.9). The leached soil treatments were also air-dried at $25^{\circ} \mathrm{C}$ and sieved through 2-mm mesh. All leached and unleached soils were stored at room temperature before starting the SIN assay.

\subsection{Substrate-induced nitrification assay}

All leached and unleached soils were used to establish a standard SIN assay (Li et al., 2009, 2010; Oorts et al., 2006b). Three replicates of $7 \mathrm{~g}$ amended soil for each $\mathrm{Pb}$ treatment were preincubated under dark aerobic conditions at $20 \pm 2{ }^{\circ} \mathrm{C}$ in 50-mL centrifuge tubes. Additional deionized water was added to adjust to $50 \pm 5 \% \mathrm{MWHC}$, taking into account the volume of 


\section{Table 1 - Selected physical and chemical properties of 17 uncontaminated soils used in the study.}

\begin{tabular}{|c|c|c|c|c|c|c|c|c|c|c|}
\hline No. & Site & Location & Soil type $\left(\right.$ GSCC $\left.^{\mathrm{a}}\right)$ & $\begin{array}{c}\mathrm{pH} \\
(1: 5)\end{array}$ & $\begin{array}{c}\mathrm{CEC} \\
\left(\mathrm{cmol}^{+} / \mathrm{kg}\right)\end{array}$ & $\begin{array}{l}\mathrm{OC} \\
(\%)\end{array}$ & $\begin{array}{c}\mathrm{EC} \\
(\mu \mathrm{S} / \mathrm{cm})\end{array}$ & $\begin{array}{c}\text { Total N } \\
(\%)\end{array}$ & $\begin{array}{c}\text { Background } \\
\mathrm{Pb}(\mathrm{mg} / \mathrm{kg})\end{array}$ & $\begin{array}{l}\text { Clay } \\
(\%)\end{array}$ \\
\hline S1 & Changsha, Hunan & $28^{\circ} 11^{\prime} \mathrm{N}, 113^{\circ} 5^{\prime} \mathrm{E}$ & Paddy soils & 3.92 & 9.3 & 1.24 & 91 & 0.15 & 40.4 & 23 \\
\hline S2 & Naning, Guangxi & $22^{\circ} 50^{\prime} \mathrm{N}, 108^{\circ} 17^{\prime} \mathrm{E}$ & Lateritic red earths & 4.34 & 10.55 & 1.73 & 30 & 0.16 & 30.8 & 43 \\
\hline S3 & Guangzhou, Guangdong & $23^{\circ} 11^{\prime} \mathrm{N}, 113^{\circ} 22^{\prime} \mathrm{E}$ & Brown earths & 4.84 & 12.43 & 2.7 & 56 & 0.18 & 16.4 & 23 \\
\hline S4 & Shangrao, Jiangxi & $28^{\circ} 25^{\prime} \mathrm{N}, 117^{\circ} 58^{\prime} \mathrm{E}$ & Red earths & 5.75 & 10.45 & 1.66 & 122 & 0.13 & 13.1 & 27 \\
\hline S5 & Jiaxing, Zhejiang & $30^{\circ} 46^{\prime} \mathrm{N}, 120^{\circ} 46^{\prime} \mathrm{E}$ & Paddy soils & 6.67 & 18.13 & 3.06 & 434 & 0.3 & 25.1 & 37 \\
\hline S6 & Jingzhou, Hubei & $30^{\circ} 39^{\prime} \mathrm{N}, 113^{\circ} 11^{\prime} \mathrm{E}$ & Yellow brown earths & 6.74 & 24.33 & 1.28 & 62 & 0.16 & 58.4 & 34 \\
\hline S7 & Harbin, Heilongjiang & $45^{\circ} 41^{\prime} \mathrm{N}, 126^{\circ} 43^{\prime} \mathrm{E}$ & Black soils & 7.26 & 22.58 & 1.37 & 141 & 0.11 & 17.6 & 21 \\
\hline S8 & Panjin, Liaoning & $41^{\circ} 2^{\prime} \mathrm{N}, 121^{\circ} 56^{\prime} \mathrm{E}$ & Meadow soils & 7.32 & 20.73 & 1.41 & 158 & 0.14 & 19.9 & 27 \\
\hline S9 & Taian, Shandong & $36^{\circ} 2^{\prime} \mathrm{N}, 116^{\circ} 56^{\prime} \mathrm{E}$ & Brown earths & 7.39 & 11.85 & 0.61 & 278 & 0.08 & 40.5 & 24 \\
\hline $\mathrm{S} 10$ & Shijiazhuang, Hebei & $37^{\circ} 46^{\prime} \mathrm{N}, 114^{\circ} 46^{\prime} \mathrm{E}$ & Fluvo-aquic soils & 7.54 & 9.25 & 1.06 & 124 & 0.12 & 23 & 26 \\
\hline S11 & Linfen, Shanxi & $36^{\circ} 6^{\prime} \mathrm{N}, 111^{\circ} 26^{\prime} \mathrm{E}$ & Cinnamon soils & 7.55 & 15.05 & 2.57 & 212 & 0.16 & 22.5 & 30 \\
\hline S12 & Kunming, Yunnan & $24^{\circ} 58^{\prime} \mathrm{N}, 102^{\circ} 42^{\prime} \mathrm{E}$ & Torrid red earths & 7.58 & 22.45 & 3.7 & 167 & 0.34 & 87.2 & 45 \\
\hline S13 & Kumul, Xinjiang & $42^{\circ} 49^{\prime} \mathrm{N}, 93^{\circ} 32^{\prime} \mathrm{E}$ & Brown desert soils & 7.62 & 12.35 & 3.19 & 237 & 0.2 & 43.3 & 19 \\
\hline S14 & Tianjin & $39^{\circ} 30^{\prime} \mathrm{N}, 117^{\circ} 35^{\prime} \mathrm{E}$ & Fluvo-aquic soils & 7.68 & 12.13 & 0.69 & 102 & 0.07 & 21.2 & 17 \\
\hline S15 & Xianyang, Shanxi & $34^{\circ} 46^{\prime} \mathrm{N}, 108^{\circ} 59^{\prime} \mathrm{E}$ & $\begin{array}{l}\text { Dark loessial soils } \\
\text { Calcareous lime }\end{array}$ & 7.77 & 9.33 & 0.49 & 109 & 0.06 & 45.8 & 22 \\
\hline S16 & Baotou, Inner Mongolia & $40^{\circ} 36^{\prime} \mathrm{N}, 109^{\circ} 59^{\prime} \mathrm{E}$ & $\begin{array}{l}\text { concretion } \\
\text { black soils }\end{array}$ & 7.78 & 11.75 & 1.64 & 370 & 0.17 & 42.3 & 20 \\
\hline S17 & Beijing & $39^{\circ} 39^{\prime} \mathrm{N}, 116^{\circ} 20^{\prime} \mathrm{E}$ & Cinnamon soils & 7.87 & 7.73 & 0.13 & 114 & 0.02 & 13.6 & 14 \\
\hline
\end{tabular}

$\left(\mathrm{NH}_{4}\right)_{2} \mathrm{SO}_{4}$ solution to be added later as substrate. After the 14-day preincubation, one tube of each $\mathrm{Pb}$ treatment was extracted with $35 \mathrm{~mL} 1.0 \mathrm{~mol} / \mathrm{L} \mathrm{KCl.} \mathrm{NH}_{4}^{+}-\mathrm{N}, \mathrm{NO}_{2}^{-} \mathrm{N}$ and $\mathrm{NO}_{3}^{-} \mathrm{N}$ were determined in these extracts using a flow injection auto-analyzer (Skalar, Holland). For the remaining tubes in each treatment, $0.5 \mathrm{~mL}$ of $0.044 \mathrm{~mol} / \mathrm{L}\left(\mathrm{NH}_{4}\right)_{2} \mathrm{SO}_{4}$ was added and the tubes were incubated for up to 14 days. The incubation time was restricted to the linear phase of soil nitrification (in control soils) and was 0 to 4 days in soils S6, S7, S8, S11, S12, S13, S14 and S16; 0 to 7 days in soils S1, S9, S10, S12, S15 and S17; 0 to 10 days in soil S2; and 0 to 14 day in soils S3, S4 and S5. After incubation, the remaining two replicates were again analyzed for $\mathrm{NH}^{4+}-\mathrm{N}, \mathrm{NO}_{2}^{-} \mathrm{N}$ and $\mathrm{NO}_{3}^{-} \mathrm{N}$ as above. Data were used to calculate the potential nitrification rate (PNR) from the linear increase in soil $\mathrm{NO}_{3}^{-} \mathrm{N}$ in the period after amendment with ammonium $\left(\mathrm{NH}_{4}^{+}\right)$salts (Smolders et al., 2001).

\subsection{Data and statistical analysis}

PNR values were calculated from the linear increase in soil nitrate plus nitrite after ammonium addition (Li et al., 2009, 2010; Oorts et al., 2006b). PNR data were fitted to a log-log doseresponse curve (Haanstra et al., 1985) in Microsoft Excel (Eq. (1)) for each of the soils using a specialized curve fitting macroroutine (Barnes et al., 2003):

$Y=\frac{Y_{0}}{1+e^{b(X-M)}}$

where $\mathrm{Y}$ is the relative PNR (\%), and $\mathrm{X}$ is the common logarithm of the measured added $\mathrm{Pb}$ concentration $(\mathrm{mg} / \mathrm{kg})$, which was the measured total $\mathrm{Pb}$ concentration in a soil minus the background $\mathrm{Pb}$ concentration. The zero metal dose for the control soil was adjusted to a very small value $(0.01 \mathrm{mg} / \mathrm{kg})$ to allow $\log$ transformation before curve fitting. The $M$ is the common logarithm of ECx (effective concentration of total $\mathrm{Pb}$ that decreased relative PNR by a user-defined percentage, i.e., EC10, EC20, EC50), $Y_{0}$ and $b$ are the curve-fitting parameters. The metal doses in soils causing 10 (EC10), 20 (EC20), and 50\% (EC50) inhibition in relative PNR and their $95 \%$ confidence intervals were derived from the fitted curve parameters and standard errors according to Haanstra et al. (1985).

Hormesis, a stimulation of response that can occur at low doses followed by inhibition at higher doses, was modeled according to Vanewijk and Hoekstra (1993) using SigmaPlot 12.5 (SPSS Inc., Chicago, IL, USA). The EC10, EC20 and EC50 values with respective $95 \%$ confidence limits were determined as follows:

$\mathrm{Y}=\frac{k \times(1+a \mathrm{X})}{1+\left(1+2 a \mathrm{EC}_{50}\right) \times\left(\mathrm{X} / \mathrm{EC}_{50}\right)}$

where $\mathrm{Y}$ is the relative PNR (\%), $\mathrm{X}$ is the added $\mathrm{Pb}$ concentration, $k$ is the untreated control, and $a$ and $b$ are the curve-fitting parameters.

Toxicity thresholds were related to soil properties (e.g., $\mathrm{pH}$, CEC, clay, OC) with enter or stepwise multiple regressions (SPSS 16.0). Parameters were log transformed when necessary after testing the data for normality and homogeneity of variance.

\section{Results}

\subsection{Soil physico-chemistry}

The 17 soils used in the present study are listed in Table 1. These soils represent the majority of Chinese soil types and cover a wide range of soil properties. Soil $\mathrm{pH}$ ranged from 3.92 at Changsha to 7.87 at Beijing. The organic carbon (OC) content was low for all soils: The maximum OC was 3.7\% at Kunming 
and 12 soils had OC values $\leq 2 \%$. Cation exchange capacity ranged from 7.73 to $24.33 \mathrm{cmol}_{\mathrm{C}} / \mathrm{kg}$, with four soils (Jingzhou, Kunming, Panjin, Haerbin) having a CEC $>20 \mathrm{cmol}_{\mathrm{C}} / \mathrm{kg}$. Background $\mathrm{Pb}$ concentrations ranged from 16 to $87 \mathrm{mg} / \mathrm{kg}$. The total concentrations of other potentially toxic elements (e.g., $\mathrm{Cu}, \mathrm{Cr}$, $\mathrm{Cd}$, and $\mathrm{Zn}$; data not shown) in the studied soils generally fell within the normal range of background levels in Chinese soils (Wei et al., 1991).

\subsection{Potential nitrification rates in uncontaminated soils}

Nitrification rates in uncontaminated soils (PNR0) ranged from $0.50 \mathrm{mg} \mathrm{N} /(\mathrm{kg} \cdot$ day) (Guangzhou) to $18.26 \mathrm{mg} \mathrm{N} / \mathrm{kg} / \mathrm{d}$ (Baotou), with $>36$-fold variation among soils. Soil nitrification rates were lowest in the four most acidic soils (S1-S4). Soil nitrification generally increased with increasing soil $\mathrm{pH}$ (Smolders et al., 2001). Stepwise multiple regression between PNRO values and soil parameters showed that $\mathrm{pH}$ was the major factor controlling PNR0, explaining $72 \%$ of the variation in PNRO. The relationship between PNRO and soil $\mathrm{pH}$ is illustrated in Fig. 2. A better prediction of PNRO was obtained by multiple regression between PNRO and soil $\mathrm{pH}$, electrical conductivity, CEC, and clay content $\left(R^{2}=0.81\right.$; Table 2).

\subsection{Dose-response curves and toxicity thresholds in leached and unleached soils}

The dose-response curves of $\mathrm{Pb}$ to SIN in leached and unleached soils are displayed in Fig. 3, and predicted EC10, EC20 and EC50 values are presented in Table 3. For unleached soils, EC10 values ranged from 7 (Changsha) to $1719 \mathrm{mg} / \mathrm{kg}$ (Shijiazhuang), EC20 values ranged from 21 (Changsha) to $2625 \mathrm{mg} / \mathrm{kg}$ (Beijing), and EC50 values ranged from 130 (Changsha) to $>2490 \mathrm{mg} / \mathrm{kg}$ (Kunming), representing 245.6-, 125-, and $>19.1$-fold variation among soils. For leached soils, EC10, EC20 and EC50 values varied from 25 to 1856, 68 to 2016, and 185 to $>2515 \mathrm{mg} / \mathrm{kg}$, respectively, representing >74.2-, > 29.6- and $>13.6$-fold variation among soils. In cases where the highest

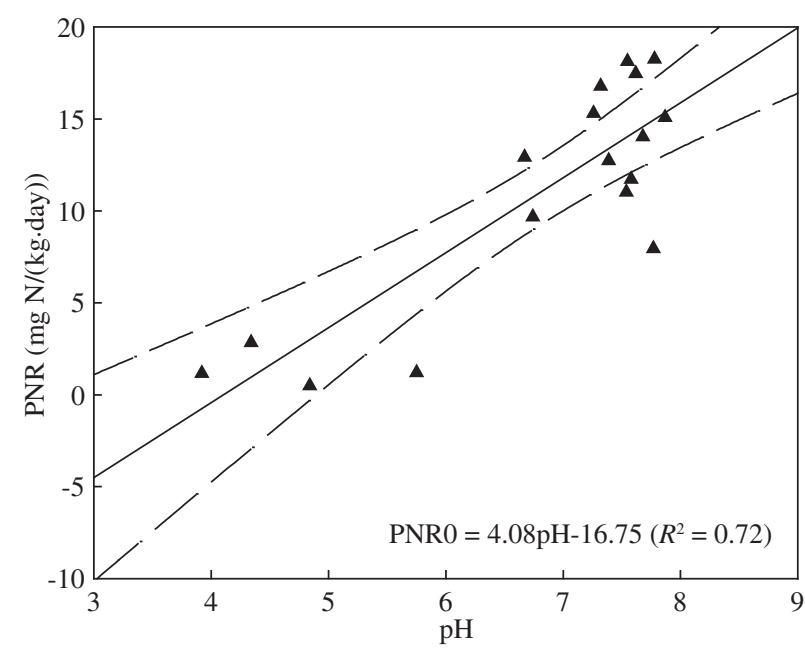

Fig. 2 - Potential nitrification rate (PNR) in the 17 unleached control soils as a function of soil $\mathrm{pH}$.
Table 2 -Simple linear regressions between potential nitrification rate in the 17 unleached control soils and soil properties.

\begin{tabular}{lcc}
\multicolumn{1}{c}{ Regression equation } & $R^{2}$ & $p$ value \\
\hline PNRO $=4.08 \mathrm{pH}-16.75$ & 0.72 & $<0.001$ \\
PNRO $=3.57 \mathrm{pH}+0.015 \mathrm{EC}-15.67$ & 0.78 & $<0.001$ \\
PNRO $=3.08 \mathrm{pH}+0.016 \mathrm{EC}+0.259 \mathrm{CEC}-$ & 0.81 & $<0.001$ \\
0.119 Clay -13.04 & & \\
\hline PNR0 = potential nitrification rate in uncontaminated soils; & EC = electrical conductivity; CEC = cation exchange capacity; \\
Clay = clay content.
\end{tabular}

concentration tested did not cause a $10 \%, 20 \%$ or $50 \%$ reduction, ECx values were not calculated because this would require extrapolation of the Concentration-Response (C-R) relationships. In addition, no net apparent loss of $\mathrm{NO}_{3}$ was observed in all cases at the higher $\mathrm{Pb}$ concentrations except for the unleached Xianyang soil at $2389 \mathrm{mg} / \mathrm{kg}$ (Fig. 3, S15). This may be the result of denitrification or nitrogen immobilization occurring at this $\mathrm{Pb}$ concentration.

A significant $(p \leq 0.05)$ increase in SIN (i.e., hormesis) with the initial increase in $\mathrm{Pb}$ concentrations was observed in five of the unleached soils (i.e., S3, S5, S10, S13 and S16) and five of the leached soils (S1, S3, S4, S8 and S10). The maximum hormesis response observed was a $13 \%$ and $36 \%$ increase over the corresponding controls for the unleached Baotou and leached Shangrao soils, respectively. Although $\mathrm{Pb}$ is a nonessential element, several studies had reported its hormetic effect for organisms and micro-organisms (Christofi et al., 2002; Wang et al., 2010).

The influence of leaching on $\mathrm{Pb}$ toxicity was found to vary among soils. A significant $(p \leq 0.05)$ decrease in $\mathrm{Pb}$ toxicity was found with leaching for nine soils (53\% of soils) for EC10 values, nine soils (53\%) for EC20 values, and 12 soils (71\%) for EC50 values. The leaching factor (LF) listed by Smolders et al. (2009) was determined by calculating the ratio of ECx in leached soil to the corresponding ECx in unleached soil, which was used to correct ecotoxicity data. Overall, for soils where SIN was inhibited sufficiently to determine the EC10 and EC20 values, LF values ranged from 0.4 to 17.84 and from 0.68 to 12.46 , respectively. Leaching increased toxicity thresholds by an average factor of 2.8 and 2.7 for EC10 or EC20 values. For the five soils where SIN was inhibited sufficiently to determine the EC50 values, LF values ranged from 1.2 to 6.68 (average 3.0).

\subsection{Multiple linear regression models to predict $\mathrm{Pb}$ toxicity in soils}

The significant $(p \leq 0.05)$ linear regression models for predicting Pb toxicity thresholds (EC10, EC20 and EC50 values) in relation to soil properties are presented in Table 4 . Soil pH was the most important single factor in predicting $\mathrm{Pb}$ toxicity for all values except the unleached EC50 value, explaining $>52 \%$ of variance in $\mathrm{Pb}$ toxicity values. For the unleached EC50 value, logCEC was found to be the best single factor in predicting $\mathrm{Pb}$ toxicity, explaining $84 \%$ of the variance of the EC50 value. A linear model, $\log$ EC50 $=0.233+0.09 \mathrm{pH}+1.836$ 


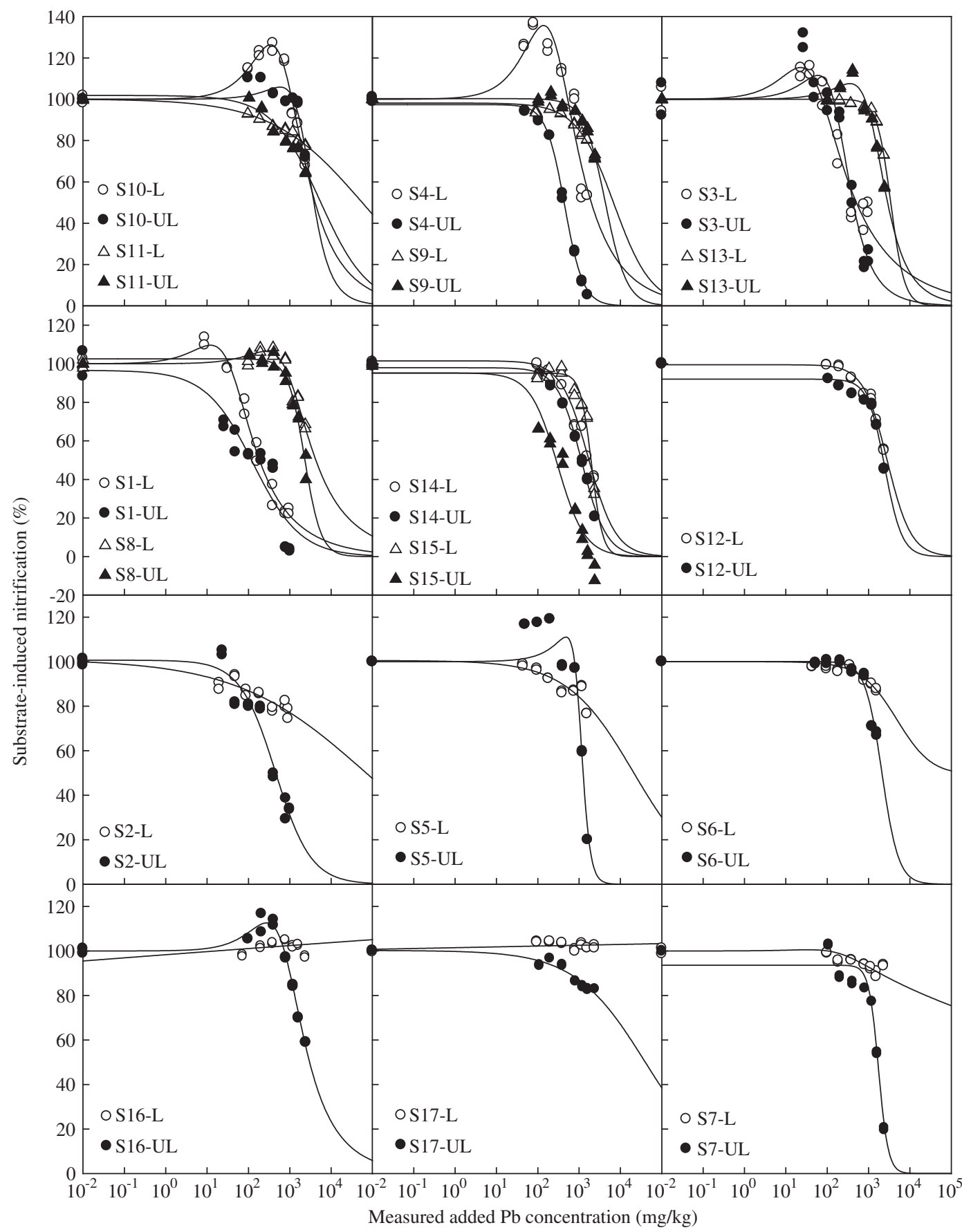

Fig. 3 - Dose-response curves of added $\mathrm{Pb}$ versus substrate-induced nitrification in 17 leached and unleached Chinese soils. Symbols represent all replicated data points. L and UL represented leached and unleached soils, respectively.

$\log$ CEC $\left(R^{2}=0.903\right)$, was able to predict the total Pb-based EC50 for 11 of the 17 unleached soils within a 2-fold range of the measured values (Fig. 4b). Factors such as TN, electrical conductivity and background $\mathrm{Pb}$ did not significantly improve the models, so they were excluded from regression equations.

\subsection{Accuracy of the relationships}

It was not possible to validate the relationships established in this study on an independent set of soil toxicity/soil property data, as all 17 soils were used to develop the models. This is a clear priority for future work. In order to provide an indication of the accuracy of the models, we determined the accuracy of the recommended relationships (Eqs. (3), (11), (15) and (18) in Table 4) by plotting measured EC10 and EC50 (EC20 for leached soils, because the largest concentration tested did not result in a $50 \%$ effect for 11 of the 17 soils) values against the values calculated by the relationships. These plots are presented in Fig. 4 and show that all the values lie within a 2-fold range of error either side of a 1:1 gradient line. 
Table 3 - Toxicity thresholds for $\mathrm{Pb}$ added to soils $(\mathrm{mg} / \mathrm{kg})$ measured by substrate-induced nitrification for $17 \mathrm{Chinese} \mathrm{soils.}$

\begin{tabular}{|c|c|c|c|c|c|c|c|c|c|c|c|c|}
\hline \multirow{2}{*}{ No. } & \multicolumn{6}{|c|}{ Unleached soil (mg/kg) } & \multicolumn{6}{|c|}{ Leached soil (mg/kg) } \\
\hline & EC10 & $95 \% \mathrm{CI}$ & EC20 & $95 \%$ CI & EC50 & $95 \%$ CI & EC10 & $95 \%$ CI & EC20 & $95 \%$ CI & EC50 & $95 \%$ CI \\
\hline $\mathrm{S} 1$ & 7 & $0-27$ & 21 & $5-50$ & 130 & $28-231$ & $50^{*}$ & $41-59$ & $68^{*}$ & $58-80$ & 185 & $160-210$ \\
\hline $\mathrm{S} 2$ & 51 & $23-83$ & 115 & $74-161$ & 451 & $314-588$ & $25^{*}$ & $8-63$ & 454 & $280-711$ & $\mathrm{NC}^{*}$ & - \\
\hline S3 & 184 & $126-243$ & 228 & $170-297$ & 422 & $324-521$ & $110^{*}$ & $78-150$ & $155^{*}$ & $117-206$ & 508 & $345-670$ \\
\hline S4 & 144 & $127-159$ & 219 & $201-236$ & 448 & $420-476$ & $668^{*}$ & $550-815$ & $843^{*}$ & 697-1032 & 1976 & $1203-2748$ \\
\hline S5 & 889 & 688-1034 & 982 & $828-1122$ & 1257 & $1120-1395$ & 357 & $200-568$ & 1598 & $990-2418$ & $\mathrm{NC}^{*}$ & - \\
\hline $\mathrm{S} 6$ & 759 & $595-900$ & 1106 & $992-1216$ & 2104 & $1753-2456$ & $1131^{*}$ & $915-1363$ & $\mathrm{NC}$ & - & $\mathrm{NC}^{*}$ & - \\
\hline S7 & 966 & $743-1116$ & 1201 & $1039-1340$ & 1744 & 1594-1893 & 1856 & 1079-3262 & $\mathrm{NC}^{*}$ & - & $\mathrm{NC}^{*}$ & - \\
\hline S8 & 825 & $672-959$ & 1198 & $1066-1325$ & 2266 & $2064-2468$ & $1089^{*}$ & $904-1283$ & $1548^{*}$ & $1353-1763$ & $\mathrm{NC}^{*}$ & - \\
\hline s9 & 1157 & $1033-1276$ & 1880 & 1770-1989 & NC & - & $710^{*}$ & $609-815$ & $1658^{*}$ & 1529-1792 & NC & - \\
\hline S10 & 1719 & $1589-1846$ & 2167 & 2022-2314 & NC & - & $1428^{*}$ & $1338-1522$ & $1805^{*}$ & $1674-1948$ & NC & - \\
\hline $\mathrm{S} 11$ & 282 & 181-399 & 835 & 681-1007 & NC & - & 223 & $181-271$ & $1712^{*}$ & $1521-1920$ & $\mathrm{NC}^{*}$ & - \\
\hline $\mathrm{S} 12$ & 872 & $644-1064$ & 1284 & $1096-1465$ & 2490 & $2137-2842$ & 654 & $547-758$ & 1123 & $1020-1228$ & $>2515^{*}$ & - \\
\hline $\mathrm{S} 13$ & 1148 & $1022-1275$ & 1478 & $1357-1604$ & NC & - & $1475^{*}$ & $1391-1555$ & $2016^{*}$ & $1952-2079$ & $\mathrm{NC}^{*}$ & - \\
\hline S14 & 263 & $221-305$ & 457 & $408-506$ & 1172 & $1084-1260$ & 317 & $228-405$ & 590 & $486-698$ & $1700^{*}$ & 1489-1911 \\
\hline S15 & 57 & $0-107$ & 105 & $55-160$ & 301 & $184-419$ & $1017^{*}$ & $841-1154$ & $1308^{*}$ & $1170-1434$ & $2012^{*}$ & $1862-2162$ \\
\hline S16 & 1006 & $938-1077$ & 1316 & $1245-1390$ & NC & - & NC & - & $\mathrm{NC}^{*}$ & - & $\mathrm{NC}^{*}$ & - \\
\hline S17 & 537 & $380-725$ & 2625 & $1887-3544$ & NC & - & NC & - & $\mathrm{NC}^{*}$ & - & $\mathrm{NC}^{*}$ & - \\
\hline
\end{tabular}

ECx $(x=10,20$ and 50): The effective concentration of added Pb that decrease substrate-induced nitrification by $10 \%, 20 \%$ and $50 \%$ of the control. $95 \%$ CI: Ranges given as $\pm 95 \%$ confidence interval.

-: The $95 \%$ CI could not be determined as the corresponding ECx values could not be determined.

NC: Toxicity threshold could not be calculated due to highest $\mathrm{Pb}$ dose measured without resulting in $50 \%$ inhibition.

* Significant difference between unleached and leached EC10 (EC20 or EC50) using T-test at $p \leq 0.05$ significance level.

\section{Discussion}

\subsection{Variation and prediction of $\mathrm{Pb}$ toxicity}

The EC50 values varied 19-fold among unleached soils in the present study. This finding can be supported by previous findings for other metals (Broos et al., 2007; Oorts et al., 2006b). Broos et al. (2007) found a 78-fold variation based on microbial assays for $\mathrm{Zn}$ in 12 Australian soils. Oorts et al. (2006b) reported that the $\mathrm{Cu}$ and $\mathrm{Ni}$ toxicity thresholds varied 19- to 90 -fold based on microbial assays in European soils. These results indicated that soil properties play a significant role in the relative bioavailability and toxicity of $\mathrm{Pb}$. Therefore, it is more reasonable to establish a site-specific guideline for $\mathrm{Pb}$ in soils rather than a single value. Efforts were made to predict $\mathrm{Pb} \mathrm{ECx}$ values using easily determined soil parameters (Table 4). As shown in Table 4, soil pH was found to be the best single factor controlling the expression of $\mathrm{Pb}$ toxicity toward SIN, explaining over $48 \%$ of the variance in ECx values for all cases. Among all soils (leached and unleached), soil $\mathrm{pH}$ was positively correlated with ECx values, indicating that as $\mathrm{pH}$ increased the $\mathrm{ECx}$ values increased. Soil CEC was another key factor for the prediction of Pb EC50 values for unleached soils, explaining approximately $84 \%$ of the variance. Incorporation of soil $\mathrm{pH}$ improved the CEC models further and explained $90 \%$ of the variance in unleached EC50 values. Several previous studies have found $\mathrm{pH}$ and CEC to be important in the prediction of ECX values (Rooney et al., 2006, 2007). Rooney et al. (2006, 2007) found strong correlations between soil CEC and the toxicity of copper and nickel to plants in a wide range of European soils. Lock and Janssen (2001) reported that soil
CEC and $\mathrm{pH}$ were the two most important soil properties affecting $\mathrm{Zn}$ ecotoxicity to soil invertebrates. Broos et al. (2007) also developed a regression model using pH $\left(r^{2}\right.$ adj $=$ $0.73)$ and CEC $\left(r^{2}\right.$ adj $\left.=0.63\right)$ for the SIN assay.

Soil $\mathrm{pH}$ and CEC have been widely recognized as the most important soil properties determining the partitioning of $\mathrm{Pb}$ in soils (Bradham et al., 2006; Buchter et al., 1989; Janssen et al., 1997; Peijnenburg et al., 1999). Buchter et al. (1989) found that pH and CEC were significantly correlated with $\mathrm{Kp}$ (partition coefficient) values for 15 elements. Janssen et al. (1997) showed that soil pH was the most important soil characteristic affecting $\mathrm{Pb}$ partitioning between the soil solid phase and soil pore water after studying the effect of soil properties on $\mathrm{Pb}$ uptake by earthworms in 20 contaminated field soils. Van den Hoop (1995) determined $\mathrm{Kp}$ values for $\mathrm{Cu}, \mathrm{Ni}, \mathrm{Pb}, \mathrm{Zn}$ and $\mathrm{Cd}$ in field soils by analyzing element concentrations directly in the pore water, and found that the Kp values correlated well with CEC. Peijnenburg et al. (1999) and Bradham et al. (2006) also reported that soil pH and CEC were the two most important parameters modulating the bioavailability and toxicity of $\mathrm{Pb}$. Our findings further indicate that soil $\mathrm{pH}$ and CEC play a crucial role in $\mathrm{Pb}$ partitioning in soil, and that partitioning is a key property controlling $\mathrm{Pb}$ toxicity in soil ecosystems. Generally, soil pH is a key factor determining the adsorption of metals in soil (Fontes and dos Santos, 2010; Sauve et al., 2000), and this is also the case for $\mathrm{Pb}$ (Harter, 1983). Therefore, high-pH soils generally lead to a high retention of soluble $\mathrm{Pb}$ added to soil. As shown in Table 3, unleached soils from Changsha, Nanning, Guangzhou and Shangrao had $\mathrm{pH}$ values $<5.8$ and had low EC50 values $(\leq 451 \mathrm{mg} / \mathrm{kg})$. In contrast, other unleached soils in this study had $\mathrm{pH}$ values $>6.6$ and had higher EC50 values 
Table 4 - Simple and multiple linear regressions between $\mathrm{Pb}$ toxicity thresholds based on added $\mathrm{Pb}$ concentrations $(\mathrm{mg} / \mathrm{kg})$ and soil properties.

\begin{tabular}{|c|c|c|c|}
\hline & Regression equation & $r^{2}$ & $p$ \\
\hline \multicolumn{4}{|c|}{ Unleached soil } \\
\hline & $\log \mathrm{EC} 10=0.104+0.36 \mathrm{pH}(n=17)$ & 0.526 & 0.001 \\
\hline 2 & $\begin{array}{l}\log \text { EC10 }=-0.233+0.4 p H+0.533 \log \\
\text { OC }(n=17)\end{array}$ & 0.611 & 0.001 \\
\hline 3 & $\begin{array}{l}\log \text { EC10 }=-1.063+0.33 p H+1.243 \log \\
\text { CEC }(n=17)\end{array}$ & 0.626 & 0.001 \\
\hline 4 & $\begin{array}{l}\log \text { EC10 }=-0.888+0.361 p H+0.862 \log \\
\text { CEC }+0.289 \log \text { OC }(n=17)\end{array}$ & 0.642 & 0.003 \\
\hline 5 & $\log \mathrm{EC} 20=0.443+0.344 \mathrm{pH}(n=17)$ & 0.594 & $<0.001$ \\
\hline 6 & $\begin{array}{l}\log \text { EC20 }=0.307+0.36 p H+0.215 \log \\
\text { OC }(n=17)\end{array}$ & 0.611 & 0.001 \\
\hline 7 & $\begin{array}{l}\log \operatorname{EC} 20=-0.237+0.327 p H+0.714 \log \\
\operatorname{CEC}(n=17)\end{array}$ & 0.635 & 0.001 \\
\hline 8 & $\begin{array}{l}\log \mathrm{EC} 20=0.121+0.337 \mathrm{pH}+0.025 \\
\operatorname{CEC}(n=17)\end{array}$ & 0.653 & 0.001 \\
\hline 9 & $\log$ EC50 $=1.574+0.21 \mathrm{pH}(n=11)$ & 0.486 & 0.017 \\
\hline & $\log \mathrm{EC} 50=0.369+2.216 \log \mathrm{CEC}(n=11)$ & 0.838 & $<0.001$ \\
\hline & $\begin{array}{l}\log \operatorname{EC} 50=0.233+0.09 \mathrm{pH}+1.836 \log \\
\operatorname{CEC}(n=11)\end{array}$ & 0.903 & $<0.001$ \\
\hline & $\begin{array}{l}\log E C 50=0.289+0.111 \mathrm{pH}+1.647 \log \\
\text { CEC }+0.166 \log \text { OC }(n=11)\end{array}$ & 0.908 & 0.001 \\
\hline \multicolumn{4}{|c|}{ Leached soil } \\
\hline & $\log \mathrm{EC} 10=0.331+0.348 \mathrm{pH}(n=15)$ & 0.657 & $<0.001$ \\
\hline & $\begin{array}{l}\log \text { EC10 }=0.41+0.347 \mathrm{pH}-0.04 \mathrm{OC} \\
(n=15)\end{array}$ & 0.662 & 0.001 \\
\hline & $\begin{array}{l}\log \text { EC10 }=0.238+0.327 \mathrm{pH}+0.016 \\
\text { CEC }(n=15)\end{array}$ & 0.678 & 0.001 \\
\hline & $\begin{array}{l}\log \text { EC10 }=0.359+0.318 p H+0.021 \\
\text { CEC }-0.077 \text { OC }(n=15)\end{array}$ & 0.695 & 0.004 \\
\hline & $\log \mathrm{EC} 20=1.112+0.273 \mathrm{pH}(n=13)$ & 0.714 & $<0.001$ \\
\hline & $\begin{array}{l}\log \text { EC20 }=0.916+0.265 \mathrm{pH}+0.229 \\
\log \mathrm{CEC}(n=13)\end{array}$ & 0.718 & 0.004 \\
\hline & $\begin{array}{l}\log \text { EC20 }=1.01+0.282 p H+0.241 \\
\log \text { OC }(n=13)\end{array}$ & 0.737 & 0.001 \\
\hline & $\begin{array}{l}\log \text { EC20 }=0.876+0.312 \mathrm{pH}-0.497 \\
\log \text { CEC }+0.019 \text { Clay }(n=13)\end{array}$ & 0.799 & 0.002 \\
\hline & $\log \mathrm{EC} 50=1.538+0.239 \mathrm{pH}(n=6)$ & 0.78 & 0.02 \\
\hline
\end{tabular}

$\mathrm{pH}=$ soil $\mathrm{pH}, \quad \mathrm{OC}=$ soil organic carbon content, $\mathrm{CEC}=$ cation exchange capacity, Clay = clay content.

(>1100 mg/kg), except for Xianyang soil (EC50 $301 \mathrm{mg} / \mathrm{kg}$ ). Several studies have reported that the concentration of dissolved $\mathrm{Pb}$ in soil solution plays a crucial role in $\mathrm{Pb}$ bioavailability and toxicity. Thus soil $\mathrm{pH}$ or CEC affects the solubility and bioavailability of $\mathrm{Pb}$ (Adriano, 2001), making it available for uptake and bioaccumulation by an organism. Badawy et al. (2002) determined the activity of $\mathrm{Pb}^{2+}$ in near-neutral and alkaline soils and found that $\mathrm{Pb}$ activity ranged from $10^{-6.73}$ to $10^{-4.83} \mathrm{~mol} / \mathrm{L}$, and was negatively correlated with soil and soil solution $\mathrm{pH}\left(r^{2}=-0.92, p<0.01\right.$ and $r^{2}=-0.89, p<0.01$, respectively). Taken together, soil $\mathrm{pH}$ and CEC were found to be the two most important soil factors for explaining the variance in $\mathrm{Pb}$ toxicity thresholds in Chinese soils. The toxicity relationships developed in the present study can assist in environmental risk assessment and improved understanding of $\mathrm{Pb}$ toxicity in soil.

\subsection{Limitations and advantages of the normalization relationships}

Generally, a difference between predicted and measured values of up to 10-fold is acceptable for ecotoxicology models such as quantitative structure-activity relationships (Blum and Speece, 1990; Pawlisz and Peters, 1993), which are used to derive water quality guidelines. The errors associated with the recommended relationships in this study were smaller than 3-fold, indicating that the relationships are suitable for use in deriving soil quality guidelines.

Several limitations exist with regard to the use of the normalization relationships developed in this study. The limitations are that they can predict only the EC50 values for the SIN assay under the experimental conditions used in the present study, and should be used only to predict the toxicity of $\mathrm{Pb}$ for soils having properties that lie within the range of values used to derive the relationships (e.g., have soil $\mathrm{pH}$ within 3.92-7.87 and/or CEC within 7.7-24.3 $\mathrm{cmol}_{\mathrm{C}} / \mathrm{kg}$ ).

Despite these limitations, normalization relationships could play a crucial role in risk and hazard assessment (Li et al., 2011; Warne et al., 2008), as they can provide estimates of the toxicity of $\mathrm{Pb}$ toward soil nitrification in soils when experimentally derived values are lacking. They could also be used to normalize toxicity for use in deriving soil quality guidelines (Li et al., 2010; Warne et al., 2008). The soil quality guidelines could be derived for soil nitrification using the relationships and could be obtained for other soil microbial processes for which there are no similar relationships by simply normalizing the data using the gradient. The advantages of these relationships are that they are based on relatively simple-to-measure soil properties, they are easy to use, they are cost-effective compared with conducting toxicity tests, and provide accurate estimates of laboratory-based toxicity (Warne et al., 2008). The usefulness of these relationships indicates that it may be possible to develop other normalization relationships for other countries in Europe, Oceania or other continents.

\subsection{Influence of soil leaching on $\mathrm{Pb}$ toxicity}

$\mathrm{Pb}$ toxicity in soils was strongly affected by the leaching treatment (Table 3). Leaching increased EC10, EC20, EC50 values by factors of $>2.75,>2.65$, and $>3.03$, respectively. Stevens et al. (2003) observed 3.0-fold reductions in $\mathrm{Pb}$ phytotoxicity to Lactuca sativa (lettuce) plants by leaching samples with artificial runoff solutions. Smolders et al. (2009) systematically investigated the effects of leaching on the EC50 values based on the total metal concentration, and reported the derived ranges of leaching factors: 0.6 to 3.6 for $\mathrm{Cu}, 0.8$ to 4.5 for Ni, 0.4 to $>8$ for $\mathrm{Pb}$, and 0.5 to 2.3 for Co. These studies present leaching factors consistent with the present study that were well below the highest leaching factor value for $\mathrm{Pb}$ (>20-fold) (Smolders et al., 2009). The most dramatic decrease in $\mathrm{Pb}$ toxicity toward SIN induced by leaching occurred in six soils (S2, S5, S6, S7, S16 and S17; Fig. 3). These soils included alkaline soil (S16 and S17), acidic soil (S2) and neutral soil (S5, S6 and S7), and the leaching effects in these soils can be attributed to different causes. Soils from Baotou and Beijing had $\mathrm{pH}$ values $\geq 7.8$ or 8.4 (measured in 

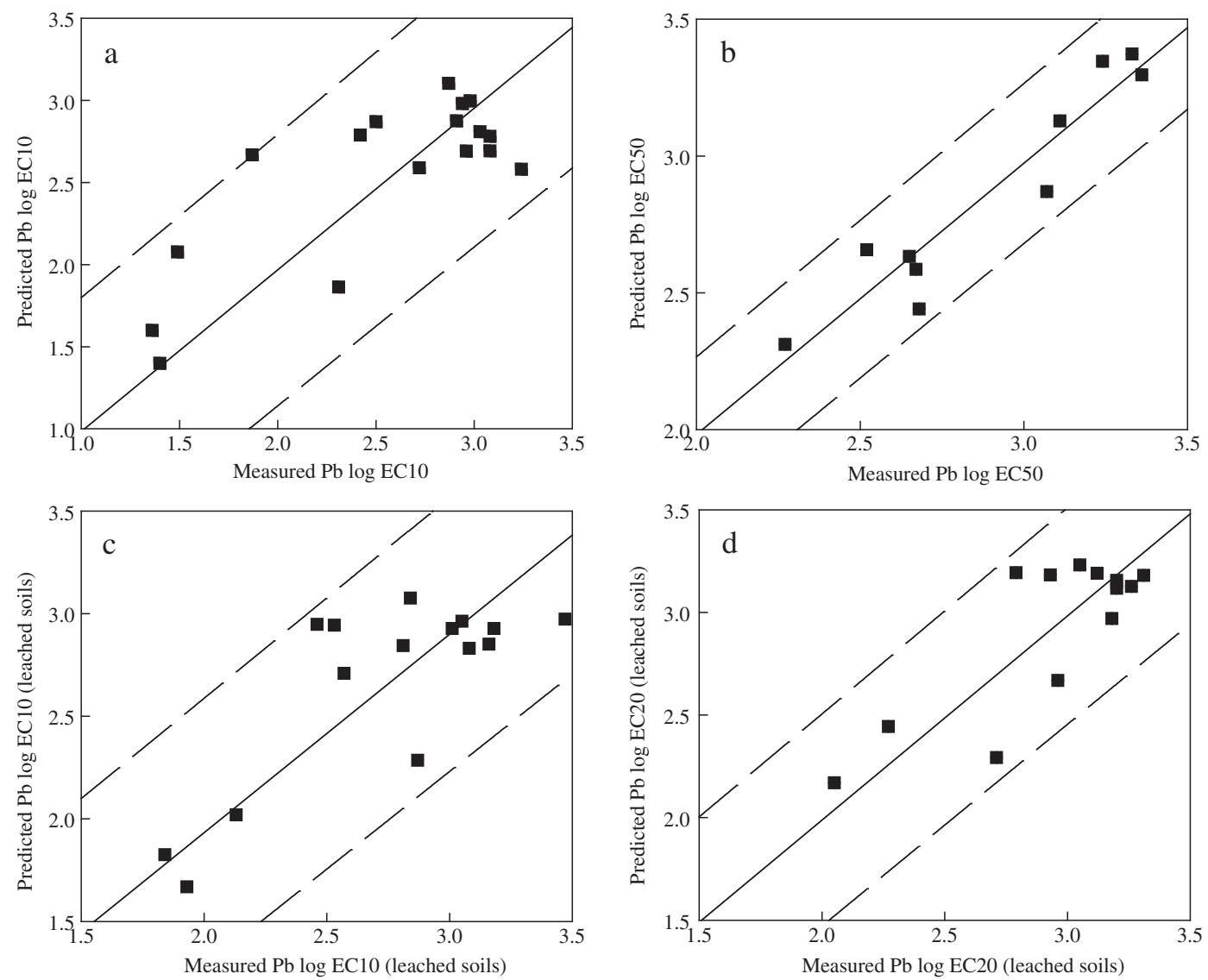

Fig. 4 - Measured toxicity values for substrate-induced nitrification assay versus predicted values using selected relationships for (a) $\mathrm{Pb} \log 10 \%$ effective concentration (EC10), (b) Pb log median effective concentration (EC50), (c) Pb log EC10 for leached soils, (d) $\mathrm{Pb} \log$ EC50 for leached soils. The solid line is $y=x+0$, and the dashed lines indicate a 2-fold error from the solid line.

deionized water without $\mathrm{CO}_{2}$ ) and the impact of leaching is likely to be because of the effects of high ionic strength and higher concentrations of other competing cations (e.g., $\mathrm{Ca}, \mathrm{Mg}$ and $\mathrm{Na}$ ). The competing cations reduce $\mathrm{Pb}$ partitioning in unleached treatment soils and therefore influence $\mathrm{Pb}$ toxicity (Garcia-Miragaya and Page, 1976; Mattigod et al., 1979; Zhu and Alva, 1993). High ionic strength reduces $\mathrm{Pb}$ sorption (Puls et al., 1991) and free metal ion activity in solution (Zhu and Alva, 1993). In addition, the competition of other cations (e.g., $\mathrm{Ca}, \mathrm{Mg}$, and $\mathrm{Na}$ ) in solution for sorption on the solid phase predominates and also reduces the partitioning of the added $\mathrm{Pb}$ (Degryse et al., 2009). The results agreed with a previous report that Ni toxicity to barley root elongation was significantly decreased by leaching in an alkaline soil $(\mathrm{pH} \geq 8.2)$ ( $\mathrm{Li}$ et al., 2011). However, in contrast to recent studies (Li et al., 2009; Schwertfeger, 2011), we found a significant decrease in $\mathrm{Pb}$ toxicity with leaching for one acidic soil (Nanning ( $\mathrm{pH} 4.34)$ ) and three neutral soils (Jiaxing ( $\mathrm{pH}$ 6.67), Jingzhou ( $\mathrm{pH}$ 6.74) and Harbin ( $\mathrm{pH}$ 7.26)). This effect can be explained by the impact of leaching on the composition of the soil solution (Li et al., 2010; Oorts et al., 2007). It has been proposed that the soluble salt contents of soil samples would increase after spiking, which is usually associated with a decrease in $\mathrm{pH}$. The "salt effect" has been observed in soil samples freshly spiked with Pb (Bongers et al., 2004; Hassan and David, 2014; Percival et al., 1999). Increased soil acidity has been linked to increased metal solubility as well as metal ion activity in soil solutions. Leaching removed excess salts, including $\mathrm{Pb}$ at higher Pb doses (Lock et al., 2006), thus increasing the EC50. The natural soil properties that mitigate metal bioavailability also influence the extent to which the salt-effect alters soil chemistry (Schwertfeger, 2011). Leaching, an artificial process, disturbed the natural soil properties. The leaching effect on $\mathrm{Pb}$ toxicity may largely depend on the leaching procedures (e.g., the duration of leaching, composition of the leaching solution, and the total volume of leaching solution) as well as soil properties, and therefore how the leaching procedure will affect the biological response. These results highlight the need for further investigation of the leaching mechanism regarding $\mathrm{Pb}$ partitioning in soils.

Finally, the results showed that the toxicity of $\mathrm{Pb}$ toward the soil nitrification process varied considerably with soil properties, with ECx varying over 13-fold in these experiments. In addition to the toxicity data that were generated, the present study showed that the addition of $\mathrm{Pb}$ to these soils resulted in considerable hormesis in a few cases. In some soils, this resulted in a response that was greater than $136 \%$ of the response observed in controls. 


\section{Conclusions}

Toxicity of $\mathrm{Pb}$ toward SIN in Chinese soils varied widely, with $>13-$ and $>19$-fold inhibition in leached and unleached soils, respectively. These variations could largely be explained by soil parameters. Multiple linear regression analysis showed that soil $\mathrm{pH}$ and CEC were the two most important factors controlling $\mathrm{Pb}$ toxicity in Chinese soils. These relationships generally predicted toxicity within a factor of two of measured values, which strengthens the case for their use in regulating metal contamination in soils. Leaching significantly reduced $\mathrm{Pb}$ toxicity in both alkaline and acidic soils. This study highlighted the need to quantitatively investigate leaching mechanisms and effects on $\mathrm{Pb}$ toxicity in soils.

\section{Acknowledgments}

This work was financially supported by the National Natural Science Foundation of China (No. 21377152), the National Science and Technology Support Program (No. 2015BAD05B02), and Central Public Research Institutes Basic Funds for Research and Development (Agro-Environmental Protection Institute, Ministry of Agriculture).

\section{R E F E R E N C E S}

Adriano, D.C., 2001. Trace Elements in Terrestrial Environments: Biogeochemistry, Bioavailability, and Risks of Metals. second ed. Springer-Verlag, New York.

Badawy, S.H., Helal, M.I.D., Chaudri, A.M., Lawlor, K., McGrath, S.P., 2002. Soil solid-phase controls lead activity in soil solution. J. Environ. Qual. 31, 162-167.

Barnes, M., Correll, R., Stevens, D., 2003. A simple spreadsheet for estimating low-effect concentrations and associated logistic dose response curves. Solutions to pollution: program abstract book. SETAC ASE Asia Pacific. The Society of Environmental Toxicology and Chemistry Asia/Pacific - Australasian

Society of Ecotoxicology, Christchurch, New Zealand, p. 156 (Sept-Oct 2003).

Blum, D.J.W., Speece, R.E., 1990. Determining chemical toxicity to aquatic species. Environ. Sci. Technol. 24, 284-293.

Bongers, M., Rusch, B., Van Gestel, C.A.M., 2004. The effect of counterion and percolation on the toxicity of lead for the springtail Folsomia candida in soil. Environ. Toxicol. Chem. 23, 195-199.

Bradham, K.D., Dayton, E.A., Basta, N.T., Schroder, J., Payton, M., Lanno, R.P., 2006. Effect of soil properties on lead bioavailability and toxicity to earthworms. Environ. Toxicol. Chem. 25, 769-775.

Broos, K., Warne, M.S.J., Heemsbergen, D.A., Stevens, D., Barnes, M.B., Correll, R.L., McLaughlin, M.J., 2007. Soil factors controlling the toxicity of copper and zinc to microbial processes in Australian soils. Environ. Toxicol. Chem. 26, 583-590.

Buchter, B., Davidoff, B., Amacher, M.C., Hinz, C., Iskandar, I.K., Selim, H.M., 1989. Correlation of Freundlich Kd and $n$ retention parameters with soils and elements. Soil Sci. 148, 370-379.

Cheyns, K., Peeters, S., Delcourt, D., Smolders, E., 2012. Lead phytotoxicity in soils and nutrient solutions is related to lead induced phosphorus deficiency. Environ. Pollut. 164, 242-247.
Christofi, N., Hoffmann, C., Tosh, L., 2002. Hormesis responses of free and immobilized light-emitting bacteria. Ecotoxicol. Environ. Saf. 52, 227-231.

Cremazy, A., Campbell, P.G.C., Fortin, C., 2013. The biotic ligand model can successfully predict the uptake of a trivalent ion by a unicellular alga below ph 6.50 but not above: possible role of hydroxo-species. Environ. Sci. Technol. 47, 2408-2415.

Degryse, F., Smolders, E., Parker, D.R., 2009. Partitioning of metals (Cd, Co, Cu, Ni, Pb, Zn) in soils: concepts, methodologies, prediction and applications - a review. Eur. J. Soil Sci. 60, 590-612.

Fontes, M., dos Santos, G., 2010. Lability and sorption of heavy metals as related to chemical, physical, and mineralogical characteristics of highly weathered soils. J. Soils Sediments 10, 774-786.

Garcia-Miragaya, J., Page, A., 1976. Influence of ionic strength and inorganic complex formation on the sorption of trace amounts of Cd by montmorillonite. Soil Sci. Soc. Am. J. 40, 658-663.

Gee, W.G., Bauder, J.W., 1986. Particle-size analysis. Methods of soil analysis. Part 1. Physical and Mineralogical Methods, second ed. American Society of Agronomy, Madison, pp. 383-411.

Giller, K.E., Witter, E., Mcgrath, S.P., 1998. Toxicity of heavy metals to microorganisms and microbial processes in agricultural soils: a review. Soil Biol. Biochem. 30, 1389-1414.

Haanstra, L., Doelman, P., Voshaar, J.O., 1985. The use of sigmoidal dose response curves in soil ecotoxicological research. Plant Soil 84, 293-297.

Harter, R.D., 1983. Effect of soil pH on adsorption of lead, copper, zinc, and nickel. Soil Sci. Soc. Am. J. 47, 47-51.

Hassan, W., David, J., 2014. Effect of lead pollution on soil microbiological index under spinach (Spinacia oleracea L.) cultivation. J. Soils Sediments 14, 44-59.

He, E., Qin, H., Dimitrova, K., Van Gestel, C.A.M., 2015. A generic biotic ligand model quantifying the development in time of $\mathrm{Ni}$ toxicity to Enchytraeus crypticus. Chemosphere 124, 170-176.

Janssen, R.P.T., Posthuma, L., Baerselman, R., Den Hollander, H.A., Van Veen, R.P.M., Peijnenburg, W.J.G.M., 1997. Equilibrium partitioning of heavy metals in Dutch field soils. II. Prediction of metal accumulation in earthworms. Environ. Toxicol. Chem. 16, 2479-2488.

Li, X.F., Huang, Y.Z., Ma, Y.B., Sun, J.W., Cui, H., 2009. Leaching impacts Ni toxicity differently among soils but increases its predictability according to nitrification assay. J. Soils Sediments 10, 579-589.

Li, X.F., Sun, J.W., Huang, Y.Z., Ma, Y.B., Zhu, Y.G., 2010. Copper toxicity thresholds in Chinese soils based on substrate-induced nitrification assay. Environ. Toxicol. Chem. 29, 294-300.

Li, B., Zhang, H., Ma, Y., McLaughlin, M.J., 2011. Influences of soil properties and leaching on nickel toxicity to barley root elongation. Ecotoxicol. Environ. Saf. 74, 459-466.

Lock, K., Janssen, C.R., 2001. Modeling zinc toxicity for terrestrial invertebrates. Environ. Toxicol. Chem. 20, 1901-1908.

Lock, K., Waegeneers, N., Smolders, E., Criel, P., Van Eeckhout, H., Janssen, C.R., 2006. Effect of leaching and aging on the bioavailability of lead to the springtail Folsomia candida. Environ. Toxicol. Chem. 25, 2006-2010.

Mattigod, S.V., Gibali, A., Page, A., 1979. Effect of ionic strength and ion pair formation on the adsorption of nickel by kaolinite. Clay Clay Miner. 27, 411-416.

Oorts, K., Bronckaers, H., Smolders, E., 2006a. Discrepancy of the microbial response to elevated copper between freshly spiked and long-term contaminated soils. Environ. Toxicol. Chem. 25, 845-853.

Oorts, K., Ghesquiere, U., Swinnen, K., Smolders, E., 2006b. Soil properties affecting the toxicity of $\mathrm{CuCl}_{2}$ and $\mathrm{NiCl}_{2}$ for soil microbial processes in freshly spiked soils. Environ. Toxicol. Chem. 25, 836-844.

Oorts, K., Ghesquiere, U., Smolders, E., 2007. Leaching and aging decrease nickel toxicity to soil microbial processes in soils freshly spiked with nickel chloride. Environ. Toxicol. Chem. 26, 1130-1138. 
Pawlisz, A.V., Peters, R.H., 1993. A test of the equipotency of internal burdens of nine narcotic chemicals using Daphnia magna. Environ. Sci. Technol. 27, 2801-2806.

Peijnenburg, W.J.G.M., Posthuma, L., Zweers, P.G.P.C., Baerselman, R., de Groot, A.C., Van Veen, R.P.M., Jager, T., 1999. Prediction of metal bioavailability in Dutch Field soils for the oligochaete Enchytraeus crypticus. Ecotoxicol. Environ. Saf. 43, 170-186.

Percival, H.J., Speir, T.W., Parshotam, A., 1999. Soil solution chemistry of contrasting soils amended with heavy metals. Soil Res. 37, 993-1004.

Puls, R., Powell, R., Clark, D., Eldred, C., 1991. Effects of pH, solid/ solution ratio, ionic strength, and organic acids on $\mathrm{Pb}$ and $\mathrm{Cd}$ sorption on kaolinite. Water Air Soil Pollut. 57-58, 423-430.

Rooney, C.P., Zhao, F.J., McGrath, S.P., 2006. Soil factors controlling the expression of copper toxicity to plants in a wide range of European soils. Environ. Toxicol. Chem. 25, 726-732.

Rooney, C.P., Zhao, F.J., McGrath, S.P., 2007. Phytotoxicity of nickel in a range of European soils: influence of soil properties, Ni solubility and speciation. Environ. Pollut. 145, 596-605.

Rusk, J.A., Hamon, R.E., Stevens, D.P., McLaughlin, M.J., 2004. Adaptation of soil biological nitrification to heavy metals. Environ. Sci. Technol. 38, 3092-3097.

Sauve, S., Hendershot, W., Allen, H.E., 2000. Solid-solution partitioning of metals in contaminated soils: dependence on $\mathrm{pH}$, total metal burden, and organic matter. Environ. Sci. Technol. 34, 1125-1131.

Schwertfeger, D., 2011. The Effects of Soil Leaching on Metal Bioavailability, Toxicity and Accumulation in Hordeum vulgare Cultivated in Copper Amended Soils Ph.D Thesis University of Mcgill, Montreal, Quebec, Canada.

Smolders, E., Brans, K., Coppens, F., Merckx, R., 2001. Potential nitrification rate as a tool for screening toxicity in metal-contaminated soils. Environ. Toxicol. Chem. 20, 2469-2474.

Smolders, E., Oorts, K., Van Sprang, P., Schoeters, I., Janssen, C.R., McGrath, S.P., 2009. Toxicity of trace metals in soil as affected by soil type and aging after contamination: using calibrated bioavailability models to set ecological soil standards. Environ. Toxicol. Chem. 28, 1633-1642.

Speir, T., Kettles, H., Percival, H., Parshotam, A., 1999. Is soil acidification the cause of biochemical responses when soils are amended with heavy metal salts? Soil Biol. Biochem. 31, 1953-1961.

Stevens, D.P., McLaughlin, M.J., Heinrich, T., 2003. Determining toxicity of lead and zinc runoff in soils: salinity effects on metal partitioning and on phytotoxicity. Environ. Toxicol. Chem. 22, 3017-3024

Van den Hoop, M.A.G.T., 1995. Metal speciation in Dutch soils: FIELD based partition coefficients for heavy metals at background levels. Rijksinstituut voor Volksgezondheid en Mileu Report 719101013, Bilthoven.

Vanewijk, P.H., Hoekstra, J.A., 1993. Calculation of the EC50 and its confidence interval when subtoxic stimulus is present. Ecotoxicol. Environ. Saf. 25, 25-32.

Wang, C.R., Tian, Y., Wang, X.R., Yu, H.X., Lu, X.W., Wang, C., et al., 2010. Hormesis effects and implicative application in assessment of lead-contaminated soils in roots of Vicia faba seedlings. Chemosphere 80, 965-971.

Warne, M.S.J., Heemsbergen, D., Stevens, D., McLaughlin, M., Cozens, G., Whatmuff, M., et al., 2008. Modeling the toxicity of copper and zinc salts to wheat in 14 soils. Environ. Toxicol. Chem. 27, 786-792.

Watanabe, M.E., 1997. Phytoremediation on the brink of commericialization. Environ. Sci. Technol. 31, 182A-186A.

Wei, F.S., Chen, J.S., Wu, Y.Y., 1991. Elemental backgroundvalues in Chinese soils. Environ. Sci. 12, 12-19.

Zhu, B., Alva, A., 1993. Differential adsorption of trace metals by soils as influenced by exchangeable cations and ionic strength. Soil Sci. 155, 61-66. 